\title{
An Analysis of Human Pathogens Found in Horse/Mule Manure Along the John Muir Trail in Kings Canyon and Sequoia and Yosemite National Parks
}

\author{
Robert Wayne Derlet, MD; James Reynolds Carlson, $\mathrm{PhD}$ \\ From the Emergency Department (Dr Derlet) and the Clinical Microbiology Laboratory (Dr Carlson), University of California, Davis, \\ Medical Center, Sacramento, CA.
}

\begin{abstract}
Objective.-To determine the prevalence of microorganisms that are potentially pathogenic for humans in horse/mule manure along the John Muir Trail (JMT).

Methods.-Random samples of horse/mule manure were collected along sections of the JMT in Yosemite, Kings Canyon, and Sequoia national parks (NP), as well as in portions of the Pacific Crest Trail (PCT) and selected JMT/PCT access trails. Convenience samples of wild animal scat found within 1 mile of trails were also collected. The fresh specimens were individually preserved both in $0.9 \%$ saline and polyvinyl alcohol (PVA)-containing tubes and stored at $4{ }^{\circ} \mathrm{C}$ until time of analysis. Bacteriological analysis was performed using standard microbiology laboratory procedures. PVA samples were stained with trichrome and were then examined by a parasitologist.

Results.-Collection: A total of 186 trail miles were sampled, including 113 on the JMT (Yosemite 37, Kings 53, and Sequoia 23). The PCT samplings included 24 miles, and NP and wilderness area access trails added an additional 49 miles. A total of 102 samples were collected, which included 81 samples from pack animals and 21 identified as having come from wild animals. Pack Animal Bacteria: All plated specimens grew large numbers of commensal gut flora. Potential pathogenic bacteria were found in only 12 samples and included Hafnia alvei (4), Serratia odorifera (1), Citrobacter freundii (1), Escherichia vulneris (1), Clostridium clostridioforme (1), Yersinia enterocolitica (1), Sherwinella putraformus (1), and Enterobacter spp (4). No Escherichia coli O157, Salmonella, or Aeromonas were found. Microscopic examination for protozoal organisms revealed occasional commensal ciliates and 1 Giardia. Wild Animal Pathogens: One specimen grew $Y$ enterocolitica, and another grew Enterobacter amnigenus.

Conclusions. - We found a low prevalence of human pathogens in pack animal manure on the JMT.
\end{abstract}

Key words: pack animals, excreta, John Muir Trail, bacteria, Hafnia

\section{Introduction}

Backpacking has become increasingly popular throughout the Sierra Nevada mountain range, and backpackers usually rely on streams and lakes along the trail as sources of drinking water. In addition to humans, certain animals such as beavers and cattle are known to serve as a reservoir for zoonotic infectious diseases that may contaminate Sierra water sources. ${ }^{1}$ Backpackers may use one of several different methods either to filter out or

Corresponding author: Robert W. Derlet, MD, University of California, Davis, Medical Center, Division of Emergency Medicine, 2315 Stockton Blvd, PSSB 2100, Sacramento, CA 95817 (e-mail: rwderlet@ucdavis.edu). destroy potential pathogenic organisms that may cause diarrhea and other illnesses. Popular portable water filtration or purifying systems use filters with small enough micropores that protect against Giardia lamblia, Cryptosporidium, and other microorganisms. ${ }^{2}$ Iodine or other halogens can be used to purify water. ${ }^{1}$ Variables in the iodination method, including 1) concentration of the pathogenic organism, 2) concentration of the halogen, 3) temperature of the water, and 4) contact with water before drinking or mixing with substance, which may neutralize the halogen, all increase the risk to backpackers for certain microorganisms.

Horses, mules, and pack trains have been a part of the Sierra high country since the 1800 s, and during the sum- 
mer months, these animals may be found in significant numbers. The Forest Service has strict controls on the number of backpackers entering wilderness areas to limit impact. However, the restrictions on pack animals operated out of commercial pack stations are unclear and have been the subject of recent debate. ${ }^{3}$

One potential problem with pack animal traffic is the amount of manure left on trails that may contain pathogens capable of causing serious infection in humans. Horses and pack animals are zoonotic reservoirs for bacteria and protozoa that may be transmitted to humans and result in illness. Species of bacteria excreted by pack animals that cause disease in humans include Yersinia enterocolitica,${ }^{4}$ Salmonella, ${ }^{5}$ Escherichia coli $\mathrm{O} 157,{ }^{6}$ and Aeromonas. ${ }^{7}$ During the spring snowmelt and runoff, the manure may be swept into adjacent creeks, and pathogenic organisms may be present in lakes for extended times. In addition, summer thundershowers may wash horse manure off the trail into streams and rivers. It is known that Giardia may last many years in cold water. The aim of this study was to determine whether specific pathogenic organisms including Salmonella, E coli $\mathrm{O} 157: \mathrm{H} 7$, and/or Giardia could be found in horse/ mule manure in quantities that could contaminate water sources for backpackers along popular sections of the John Muir Trail (JMT) and other high Sierra trails.

\section{Methods}

Samples of fresh horse/mule manure were collected along sections of the JMT in the Yosemite, Kings Canyon, and Sequoia national parks (NP). In addition, popular access trails to the JMT, Pacific Crest Trail (PCT), and portions of the PCT trail between Lake Tahoe and Yosemite were also sampled. Specimens were collected on multiple overnight trips from August to September 2000. Specimens eligible for collection were only those that were relatively fresh as defined by the presence of flies, manure odor, or noticeable moisture in or about the specimen. The trail prevalence or "frequency" of manure was recorded as manure sites per mile. One manure site was defined as all manure found within a 30 -foot length of trail. Trails were divided into 2-mile sections, and 1 specimen was collected within each section. Manure sites within these sections were selected by convenience. On heavily contaminated trails, 2 samples were taken within each section. Heavily manured trails were defined as having 10 or more manure sites per mile. Convenience samples of wild animal scat found within 1 mile of trails were also collected. One of the authors (R.D.) has experience in identifying horse, mule, deer, marmot, and other samples of scat from the Sierra Nevada range using accepted guides. ${ }^{8}$
The collected specimens were immediately divided between two 5-mL screw-cap tubes-one containing $0.9 \%$ saline and the other containing polyvinyl alcohol (PVA) - before transport to the University of California, Davis, Medical Center Clinical Microbiology Laboratory. Specimens were refrigerated and stored at $4^{\circ} \mathrm{C}$ within 96 hours of collection.

Bacteriological analysis was performed by plating each of the samples onto each of the following agar plates: sheep blood agar, MacConkey agar, sorbitol MacConkey agar, and Hektoen agar. Nonsorbitol fermenting colonies that grew on the sorbitol MacConkey plate were further screened for E coli $\mathrm{O} 157$ by performing an antigen-specific latex-agglutination test. Identification of Salmonella or Yersinia spp was performed by subplating lactose-negative Hektoen nonfermenters onto triple sugar iron agar and lysine iron agar slant tubes. Isolates displaying characteristics of pathogenic bacteria were then further tested using standard microbiology laboratory techniques. ${ }^{9-12}$

To determine the effectiveness of bacterial preservation during transport and storage, selected samples underwent further testing. Gram stains of colonies that grew on sheep blood agar were performed. Selected gram-negative colonies were analyzed for general identification using a septor panel analyzer. Anaerobic incubation and identification of anaerobes following standard clinical lab procedures were also performed on selected samples. ${ }^{13}$

Samples preserved in PVA for Giardia analysis were applied to glass slides and prepared for trichrome staining. A microscopic examination by a trained parasitologist was performed.

\section{Results}

\section{SAMPLE COLLECTION}

A total of 186 trail miles were sampled, including 113 on the JMT (Yosemite NP 37 miles, Kings Canyon NP 53 miles, and Sequoia NP 23 miles). PCT samplings included 24 miles, and NP and wilderness area access trails added an additional 49 miles.

The incidence of manure sites varied widely and is displayed in Table 1. Highest concentrations were found along the Tuolumne-Glen Alun Trail in Yosemite NP, and the lowest were found along the JMT in the Mather Pass area of Kings Canyon NP. Some 2-mile sections of trail were devoid of pack animal manure.

A total of 102 samples were collected, which included 79 samples from pack animals and 23 identified as having come from wild animals. One pack animal sample taken in Kings Canyon NP was found to have dried be- 
Table 1. Incidence of manure on selected trails*†

\begin{tabular}{|c|c|c|c|c|}
\hline Wilderness (place) & Trail & Trail location & $\begin{array}{c}\text { Distance } \\
\text { surveyed } \\
\text { (miles) }\end{array}$ & $\begin{array}{c}\text { Manure sites } \\
\text { per mile }\end{array}$ \\
\hline Yosemite & PCT & Tuolomne-Glen AuLin & 6 & $20-40 \ddagger$ \\
\hline Yosemite & JMT & Tuolumne-Sunrise & 6.6 & 20 \\
\hline Yosemite & JMT & Tuolumne-Donahue Pass & 13 & $10-20$ \\
\hline Tahoe National Forest & PCT & Echo Summit to Bryon Meadow & 4 & 2.2 \\
\hline Mokulumne & PCT & Sunset Lake to Raymond Creek & 13 & 1.0 \\
\hline Kings Canyon & JMT & Woods Crossing to Rae Lake & 6.3 & 0.9 \\
\hline Kings Canyon & JMT & Bench Lake Junction to Woods Crossing & 13 & 0.5 \\
\hline
\end{tabular}

*Table depicts only 61.9 of 186 miles sampled.

$\dashv$ PCT indicates Pacific Crest Trail; JMT, John Muir Trail.

$\$$ Range noted where large variations occurred along the same trail.

cause of leakage of the saline transport media. Because of the potential for contamination by bacteria after collection, this 1 specimen was discarded from bacterial analysis.

\section{PACK ANIMAL BACTERIA}

Of all plated specimens tested, each grew many morphologically different colonies on sheep blood, MacConkey, sorbitol MacConkey, and Hektoen agars. All 4 quadrants of each sheep blood and MacConkey plates grew out organisms, indicating a high concentration of viable bacteria in each specimen. Gram stains of selected colonies revealed gram-positive cocci resembling Enterococcus, gram-positive rods, and gram-negative rods resembling common enteric organisms. The most commonly identified bacteria included $E$ coli, Bacillus, and Enterococcus spp. The proportion of individual bacterial types varied among samples, creating a different fingerprint for each sample, validating that each sample was unique. A total of 25 pack animal samples grew nonfermenting $E$ coli colonies on sorbitol MacConkey plates; however, latex-agglutination tests failed to confirm $E$ coli $\mathrm{O} 157$.

Enteric bacteria that may have pathogenic potential in susceptible individuals were identified as follows: Hafnia alvei (4), Enterobacter clocae (2), C clostridioforme (1), Serratia odorifera (1), Citrobacter freundii (1), Sherwinella putraformus (1), Escherichia vulneris (1), $Y$ enterocolitica (1), Enterobacter asburia (1), and Enterobacter ns (1). One sample contained 2 pathogenic organisms. Table 2 shows the distribution of pathogens by geographic area. The JMT in northeastern Kings Canyon NP had the lowest incidence of pathogens ( 1 of 25 samples), whereas other areas had higher concentrations of pathogens.

\section{WILD ANIMAL BACTERIA}

Similar to pack animals, specimens grew multiple colonies of Enterococcus, Bacillus spp, and enteric gramnegative rods (Table 3). Pathologic bacteria were found in only 2 specimens. Scat from an unidentified wild animal in the Bishop Pass area of northeast Kings Canyon NP grew out $Y$ enterocolitica. Enterobacter amnigenus was found in a deer specimen near Lake Tahoe.

\section{GIARDIA}

Giardia was identified in 1 pack animal sample near Tuolumne Meadows.

Five other samples from pack animals along the JMT had symbiotic ciliates including Blepharosphaera, Endolimax nana, and Beutschlii.

\section{Discussion}

The JMT from Yosemite Valley to the Mount Whitney Summit measures 210 miles. Our sampling of 113 miles provides an analysis of over $50 \%$ of the JMT and nearly $83 \%$ of the NP portions of the JMT. An additional 49 miles of JMT/PCT access trails and 24 miles of PCT trails also provided information on human pathogens in the Sierra Nevada mountain range. Significant amounts of pack animal manure were found in many sections of the JMT along the trails, especially in Yosemite. In the authors' opinion, the high incidence of manure along the trails significantly decreased aesthetic value as well as wilderness experience. However, many more remote sections of the trail contained low concentrations of manure.

We were surprised at the finding of large numbers of viable enteric bacteria, which grew out when each spec- 
Table 2. Microbiologic analysis of fecal excreta: pack animals*

\begin{tabular}{|c|c|c|c|c|c|}
\hline & $\begin{array}{l}\text { Total no. } \\
\text { samples }\end{array}$ & $\begin{array}{c}\text { No. samples } \\
\text { with enteric } \\
\text { gram }+\end{array}$ & $\begin{array}{l}\text { No. samples } \\
\text { with enteric } \\
\text { gram - }\end{array}$ & $\begin{array}{l}\text { No. samples } \\
\text { with } \\
\text { potential } \\
\text { pathogens }\end{array}$ & Potentially pathogenic organisms \\
\hline \multicolumn{6}{|l|}{ JMT: } \\
\hline Yosemite NP & 12 & 12 & 12 & 3 & $\begin{array}{l}\text { Hafnia alvei }(1) \\
\text { Escherichia vulneris }(1) \\
\text { Citrobacter freundii (1) }\end{array}$ \\
\hline Kings Canyon/Sequoia NP & 17 & 17 & 17 & 1 & H. alvei (1) \\
\hline \multicolumn{6}{|l|}{ Other trails: } \\
\hline Yosemite NP & 16 & 16 & 16 & 2 & $\begin{array}{l}\text { Giardia (1) } \\
\text { Sherwinella putraformus }\end{array}$ \\
\hline Kings Canyon NP (JMT access) & 6 & 6 & 6 & 3 & $\begin{array}{l}\text { H. alvei (1) } \\
\text { Clostridium clostridioform } \\
\text { Enterobacter clocae }(1)\end{array}$ \\
\hline PCT (non-NP) & 22 & 22 & 22 & 3 & $\begin{array}{l}\text { E. clocae (1) } \\
\text { Yersinia enterocolitica (1) } \\
\text { Enterobacter ns (1) }\end{array}$ \\
\hline PCT access & 8 & 8 & 8 & 3 & $\begin{array}{l}\text { Serratia odorifera }(1) \\
\text { H alvei (1) } \\
\text { Enterobacter asburia (1) }\end{array}$ \\
\hline Totals & 81 & 81 & 81 & 15 & \\
\hline
\end{tabular}

*JMT indicates John Muir Trail; NP, National Park; and PCT, Pacific Crest Trail.

imen was plated in the laboratory. We had postulated that, because of exposure on the trail to extreme temperatures and direct sunlight, many samples would have small amounts of bacteria and only 1 or 2 surviving species. Therefore, much of the manure encountered by the hiker is teeming with assorted commensal pack animal bacteria. The chief aim of the bacteriologic analysis was to identify E coli $\mathrm{O} 157$ and Salmonella. Neither organism was identified in our analysis. Therefore, at least in these limited samplings, pack animals have a low likelihood of importing E coli O157 and Salmonella into wilderness areas.

However, small amounts of pack animal manure did contain other microorganisms capable of human disease. $H$ alvei was identified in 4 pack animal specimens. $H$ alvei is a gram-negative facultative bacillus that belongs

Table 3. Microbiologic analysis of fecal excreta: wild animals*

\begin{tabular}{|c|c|c|c|c|c|}
\hline & $\begin{array}{c}\text { Total no. } \\
\text { samples }\end{array}$ & $\begin{array}{c}\text { No. samples } \\
\text { with enteric } \\
\text { gram }+\end{array}$ & $\begin{array}{c}\text { No. samples } \\
\text { with enteric } \\
\text { gram - }\end{array}$ & $\begin{array}{c}\text { No. samples } \\
\text { with } \\
\text { pathogens }\end{array}$ & Potentially pathogenic organisms \\
\hline \multicolumn{6}{|l|}{ JMT: } \\
\hline Yosemite NP & 2 & 2 & 2 & 0 & \\
\hline Kings Canyon/Sequoia NP & 8 & 8 & 8 & 0 & \\
\hline \multicolumn{6}{|l|}{ Other trails: } \\
\hline Yosemite NP & 2 & 2 & 2 & 0 & \\
\hline Kings Canyon NP (JMT access) & 3 & 3 & 3 & 1 & Yersinia enterocolitica (1) \\
\hline PCT (non-NP) & 3 & 3 & 3 & 1 & Enterobacter amnigenus (1) \\
\hline PCT access & 2 & 2 & 2 & 0 & \\
\hline Totals & 20 & 20 & 20 & 2 & \\
\hline
\end{tabular}

\footnotetext{
*JMT indicates John Muir Trail; NP, National Park; and PCT, Pacific Crest Trail.
} 
to the family Enterobacteriae. ${ }^{14}$ Sophisticated laboratory techniques such as ours need to be used to avoid false identification of certain Hafnia strains. ${ }^{15}$ This organism has been found to cause human diarrheal disease and other intestinal disorders in a number of environments. ${ }^{16-20}$ It has also been found in a number of mammalian hosts. ${ }^{21}$ Some Hafnia strains, which possess the attachment effacement gene (eaeA), may have clinical importance as an emerging human pathogen. ${ }^{22}$ Of equal concern are reports that resistance to beta-lactamase can be derived from chromosome-encoded sections of Hafnia that are transferred to Klebsiella and E coli strains. ${ }^{23,24}$ Reports of diarrheal disease from $H$ alvei in Sierra Nevada hikers have not been published. However, this is a pathogen that could be potentially ingested through untreated Sierra water. $Y$ enterocolitica was isolated from 1 wild animal estimated to be a medium-sized mammal. This is consistent with previously published studies. One study of 34 sites of lake and stream water in the Mammoth Lakes areas found $Y$ enterocolitica at 10 of the sites. ${ }^{25}$ Another study isolated $Y$ enterocolitica from 10 of 121 soil samples taken in northwest California. ${ }^{26} Y$ enterocolitica has been associated with appendicitis both in this country and abroad. ${ }^{27}$ Yersinia has also been described in small wild animals in Japan. ${ }^{28}$

The potential for finding Giardia or Cryptosporidium in pack animals manure also exists. A study of horses in Kentucky and Ohio showed that Giardia was present in $17 \%$ to $35 \%$ of samples, and Cryptosporidium was present in $15 \%$ to $31 \% .^{29}$ Studies of farm animals in Canada have reported that $20 \%$ of horses are infected with Giardia and $17 \%$ with Cryptosporidium. ${ }^{30}$ Studies from Europe suggest this might be a worldwide problem. ${ }^{31}$ However, a 1997 report did not find any Giardia or Cryptosporidium in 91 horses used for backcountry recreation in California. ${ }^{32}$ Our finding of 1 Giardia is consistent with this study. These 2 studies taken together suggest that the risk of pack animals and horses importing Giardia into the Sierra watershed is relatively low.

There are limitations in this study. Although extensive care and planning were taken in executing this study, it does have several potential weaknesses. This study sampled manure only during the months of August and September, but potentially, there could be other months in the Sierra when other pack animals could introduce pathogens. Although every attempt was made to preserve specimens, it is possible that some bacteria may have died during transport back to cold storage. Against this hypothesis is the fact that large numbers of bacteria were found in all sealed samples. We believe our collection and preservation system would have identified significant pathogens, as many nonpathogenic bacteria with similar environmental and nutritional requirements were cultured from the samples. It is possible, although unlikely, that duplicate samples were taken along a trail. The probability of this is low because of the large numbers of manure sites and, upon plating in the lab, the proportion of different organisms was unique to each sample. In addition, within a given stretch of 10 miles, manure samples with different morphologic characteristics and of different ages were collected. Finally, it is possible that because of extreme heat, cold, and intense sunlight, certain pathogenic bacteria may have died before being collected. However, this is unlikely because bacteria with similar nutritional and environmental requirements were easily cultured from samples.

\section{Conclusion}

Pack animal manure commonly encountered by backpackers on Sierra Nevada trails contains large numbers of commensal enteric bacteria normally found in animals. Human pathogens with potential medical importance are present but have a low prevalence.

\section{Acknowledgment}

Supported by a Wilderness Medical Society Hultgren Grant.

\section{References}

1. Backer HD. Field water disinfection. In: Auerbach PS, ed. Wilderness Medicine. St Louis, MO: Mosby Inc; 2001: 1186-1236.

2. Gerba CP, Naranjo JE. Microbiological water purification without the use of chemical disinfection. Wilderness Environ Med. 2000;11:12-16.

3. US Department of Agriculture. US Forest Service Pacific Southwest Region: Ansel Adams, John Muir, Dinkey Lakes and Monarch Wilderness: Special Newsletter, April 2000. Washington, DC: USDA; 2000.

4. Butler T. Yersinia species, including plague. In: Mandel GL, Bennett JE, Dolin R, eds. Mandell, Douglas, Bennett's Principles and Practice of Infectious Diseases. 5th ed. Philadelphia, PA: Churchill Livingstone; 2000:24062414.

5. Humphrey TJ, Threlfall EJ, Cruickshank JG. Salmonellosis. In: Palmer SR, Soulsby L, Simpson DIH, eds. Zoonoses. New York, NY: Oxford University Press; 1998: 191-206.

6. Nelson S, Clarke RC, Karmali MA. Verocytotoxin-producing Escherichia coli (VTEC) infections. In: Palmer SR, Soulsby L, Simpson DIH, eds. Zoonoses. New York, NY: Oxford University Press; 1998:89-104.

7. Hathcock TL, Schumacher J, Wright JC, Stringfellow J. 
The prevalence of Aeromonas species in feces of horses with diarrhea. J Vet Intern Med. 1999;13:357-360.

8. Farrand J. Familiar animal tracks of North America. In: National Audubon Society Pocket Guide. New York, NY: Chanticleer Press; 1998:1-192.

9. Schreckenberger PC, Janda JM, Wong JD, Barron EJ. Algorithms for identification of aerobic gram-negative bacteria. In: Murray PR, Barron EJ, Pfaller MA, Tenover FC, Yolken RH, eds. Manual of Clinical Microbiology. Washington, DC: American Society for Microbiology; 1999: 438-441.

10. Farmer JJ III. Enterobacteriaceae: introduction and identification. In: Murray PR, Barron EJ, Pfaller MA, Tenover FC, Yolken RH, eds. Manual of Clinical Microbiology. Washington, DC: American Society for Microbiology; 1999:442-458.

11. Bopp CA, Brenner FW, Wels JG, Strockbine NA. Escherichia, Shigella and Salmonella. In: Murray PR, Barron EJ, Pfaller MA, Tenover FC, Yolken RH, eds. Manual of Clinical Microbiology. Washington, DC: American Society for Microbiology; 1999:459-474.

12. Aleksic S, Bockemuhl J. Yersinia and other enterobacteriaceae. In: Murray PR, Barron EJ, Pfaller MA, Tenover FC, Yolken RH, eds. Manual of Clinical Microbiology. Washington, DC: American Society for Microbiology; 1999:483-496.

13. Engelkirk PG, Duben-Engelkirk J, Dowell VR. 1992. Principles and Practice of Clinical Anaerobic Bacteriology. Belmont, CA: Star Publishing; 1992.

14. Rodriguez LA, Vivas J, Gallardo CS, Acosta F, Barbeyto L. Identification of Hafnia alvei with the MicroScan WalkAway system. J Clin Microbiol. 1999;37:4186-4188.

15. Janda JM, Abbott SL, Albert MJ. Prototypal diarrheagenic strains of Hafnia alvei are actually members of the genus Escherichia. J Clin Microbiol. 1999;37:2399-2401.

16. Albert MJ, Alam K, Islam M, Montanaro J, Rahman ASMH. Hafnia alvei, a probable cause of diarrheal illness in humans. Infect Immun. 1991;59:1507-1513.

17. Ratnam S. Etiologic role of Hafnia alvei in human diarrheal illness. Infect Immun. 1991;59:4744-4745.

18. Ratnam S, Butler RW, March S, Parsons S, Clarke P. Enterobacter hafniae-associated gastroenteritis-Newfoundland. Can Dis Wkly Rep. 1979;5:231-232.
19. Reina J, Hervas J, Borrell N. Acute gastroenteritis caused by Hafnia alvei in children. Clin Infect Dis. 1993;16:433.

20. Westblom TU, Milligan TW. Acute bacterial gastroenteritis caused by Hafnia alvei. Clin Infect Dis. 1992;14:12711272 .

21. Gordon DM, FitzGibbon F. The distribution of enteric bacteria from Australian mammals: host and geographical effects. Microbiology 1999;145:2663-2671.

22. Ridell J, Siitonen A, Paulin L, Lindroos O, Korkeala H. Characterization of Hafnia alvei by biochemical tests, random amplified polymorphic DNA PCR, and partial sequencing of 16S rRNA gene. J Clin Microbiol. 1995;33: 2372-2376.

23. Nadjar D, Rouveau M, Verdet C, Donayb L, Herrmann J. Outbreak of Klebsiella pneumoniae producing transferable AmpC-type beta-lactamase (ACC-1) originating from Hafnia alvei. FEMS Microbiol Lett. 2000;187:35-40.

24. Ismaili A, Bourke B, de Azavedo JC, Ratnam S, Karmali MA. Heterogeneity in phenotypic and genotypic characteristics among strains of Hafnia alvei. J Clin Microbiol. 1996;34:2973-2979.

25. Harvey S, Greenwood JR, Pickett MJ, Mah RA. Recovery of Yersinia enterocolitica from streams and lakes of California. Appl Environ Microbiol. 1976;32:352-354.

26. Botzler RG. Yersiniae in the soil of an infected wapiti range. J Wildlife Dis. 1979;15:529-532.

27. Bennion RS, Thompson JE Jr,Gil J, Schmit PJ. The role of Yersinia enterocolitica in appendicitis in the southwestern United States. Am Surg. 1991;57:766-768.

28. Kaneko K, Hashimoto N. Occurrence of Yersinia enterocolitica in wild animals. Appl Environ Microbiol. 1981; 41:635-638.

29. Xiao L, Herd RP. Epidemiology of equine cryptosporidium and giardia infections. Equine Vet J. 1994;26:14-17.

30. Olson ME, Thorlakson CL, Deselliers L, Morck DW, McAllister TA. Giardia and cryptosporidium in Canadian farm animals. Vet Parasitol. 1997;68:375-381.

31. Pavlasek I, Hess L, Stehlik I, Stika V. The first findings of giardia spp. in horses in the Czech Republic. Vet Med. 1995;3:81-86.

32. Johnson E, Atwill ER, Filkins ME, Kalush J. The prevalence of shedding of cryptosporidium and giardia spp. based on a single fecal sample collection from each of 91 horses used for backcountry recreation. J Vet Diagn Invest. 1997;9:56-60. 